\title{
VITRÚVIO. Tratado de arquitectura (tradução do latim, introdução e notas por M. Justino Maciel). Lisboa: IST Press, 2006,
}

Júlio César Vitorino Universidade Federal de Minas Gerais

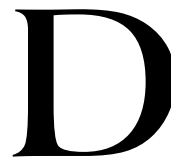

esperta curiosidade o fato de não existir, até muito recentemente, uma tradução completa em língua portuguesa da obra de Vitrúvio, escrita originalmente em latim e publicada por volta do ano de 27 a.C., conhecida como De architectura libri decem. $\mathrm{Na}$ verdade, sabe-se que por volta de 1541, D. João III encomendou uma tradução ao célebre matemático João Nunes, mas, caso esse projeto tenha sido levado a cabo, o texto teria sido levado para Madrid em época filipina, não tendo sido até hoje localizado. Em 1999, foi publicada, no Brasil, a primeira tradução integral da obra em português, de autoria de Marco Aurélio Lagonegro, para a qual existem planos de uma terceira edição, dessa vez com o texto latino à fronte, já tendo sido vendidos no total cerca de dez mil exemplares, o que demonstra o interesse, também no Brasil, por esse célebre tratado.

A edição da nova tradução se apresenta em uma elegante versão editorial acompanhada com as ilustrações feitas por Thomas Noble Howe para a sua tradução em inglês, em conjunto com I. D. Rowland, publicada pela Cambridge University Press em 1999. Realmente, uma dificuldade adicional, não só para a tradução, mas para a própria compreensão da obra de Vitrúvio, é constituída pelo desaparecimento completo das ilustrações que deviam acompanhar o manuscrito original, às quais o autor faz diversas alusões no texto e seriam complementares às suas explicações.

Em relação ao lançamento da IST Press, observa-se que algumas vezes as ilustrações apresentadas não têm apoio no aparato explicativo, ao contrário da edição inglesa, de modo que para o leitor muitas 
vezes se torna difícil compreender os esquemas apresentados. Por exemplo, na figura 24, aparece uma alusão ao único método descritivo arqueologicamente documentado, mais exatamente ao método descoberto por Haselberger para a realização da curvatura no corpo vertical da coluna, ou êntase, no entanto essa "citação" não é explicada no texto e nem nas breves (mas numerosas) notas de comentário que o acompanham e nem sequer nas legendas que acompanham o desenho. Deve-se ressaltar, porém, que os desenhos têm um sólido estudo arqueológico por trás da sua execução e que, além da beleza adicional que conferem ao projeto editorial, serão de grande utilidade para o leigo, para o curioso, para o estudioso e também para o especialista.

Quanto ao texto, a iniciativa de Justino Maciel é louvável e terá, certamente, muito boa acolhida também entre o público brasileiro. Em primeiro lugar, a introdução que antecede a tradução, apresenta um bom status quaestionis dos estudos vitruvianos, recorrendo à opinião dos maiores especialistas na apresentação do autor e da estrutura do tratado. Em relação à nova tradução, é bom lembrar que o próprio autor latino já sentia dificuldade em expressar, em latim, conceitos muitas vezes provenientes da Grécia e, segundo as palavras de Justino Maciel, traduzir Vitrúvio não é fácil, pois se trata de um texto que nos é transmitido com uma linguagem pragmática em que, apesar de uma certa literariedade nos preâmbulos, sobressai a objetividade e o discurso denotativo. Assim, o tradutor procura transferir a mensagem latina com as suas características próprias, mantendo o paralelismo discursivo, sempre que possível. Quando a tradução literal origina repetições, redundâncias ou menor clareza, a sua versão apresenta-se com maior liberdade discursiva, procurando sempre respeitar a linha de pensamento do autor. O resultado é um texto mais coerente com o estágio atual dos estudos vitruvianos e também, mesmo para o leitor brasileiro, mais fácil de ser lido e compreendido que a tradução de Lagonegro.

O texto latino que serviu de base à tradução é o de Granger (1931), que privilegia o manuscrito mais antigo entre os que conservaram a obra de Vitrúvio (Harleianus 2767, do British Museum), demonstrando uma tendência à valorização do "bom manuscrito" que nem sempre tem apoio filológico, mas que não é raro no âmbito dos estudos vitruvianos, podendo-se citar, na mesma linha, além de Granger, também a edição sui generis 
de Ferri (1960). O tradutor, no entanto, diz ter recorrido a variantes de outros manuscritos, a partir das edições críticas de Fensterbush e da $C U F$, sempre que lhe suscitaram problemas na interpretação do texto e na sua lógica interna, o que não implica necessariamente em trabalho filológico de alto nível, mas demonstra a sua preocupação em dar espaço a discussões de natureza filológica.

O texto apresentado é dividido em capítulos e parágrafos numerados, conforme prática atualmente muito seguida. A opção por dar um título a cada parágrafo, no entanto, ainda que possa ser útil ao leitor interessado em assuntos específicos, às vezes pode se demonstrar prejudicial à leitura, visto que nem sempre o título corresponde perfeitamente ao conteúdo do parágrafo, de modo que tais subtítulos poderiam ser mais específicos ou mais genéricos, como no caso do título do parágrafo 1.5.2. "Levantamento das torres", para oferecer só um exemplo, em que se fala também de muralhas e portas.

No âmbito da tradução, por se tratar de uma obra de literatura técnica, o primeiro problema que se coloca é a expressão da própria nomenclatura grega e latina utilizada por Vitrúvio e a sua transposição para uma língua moderna. Utilizar conceitos arquitetônicos atuais, como predomina na tradução de Lagonegro, parece modernizar excessivamente o texto vitruviano, enquanto o recurso mais sóbrio à simples transliteração dos mesmos e que predomina no texto de Justino Maciel, também não é sempre satisfatório. No caso do grego symmetría, por exemplo, transposto para o latim por Vitrúvio como simmetria, o tradutor prefere a transposição semântica, utilizando "comensurabilidade", para evitar contaminações com o significado atual do termo moderno "simetria", pois o conceito vitruviano se refere a um sistema inter-relacional de módulos. Em outros casos, impõe-se o uso de formas perifrásticas; por exemplo, para o tradutor, a palavra oppidum parece ser sinônima de moenia e de ciuitas; contudo, ele observa que moenia é usado mais com valor metonímico tomando a parte fortificada pelo conjunto da cidade e ciuitas enfatiza o conceito jurídico da cidade como referência para os cidadãos: assim ele traduz, preferencialmente, o primeiro termo com "opido" (cidade fortificada), o segundo com "recinto murado" e só o terceiro com "cidade".

Também no caso dos passos obscuros da obra, creio que essa nova tradução será de maior proveito ao leitor, pois se nota que houve um empenho efetivo por parte do tradutor para compreender as 
questões envolvidas, embora falte um comentário mais desenvolvido nesses casos. Assim, por exemplo, na famosa questão dos scamilli inpares vitruvianos, no livro III, uma expressão que Lagonegro traduz com um anacrônico "pedestais assimétricos", Justino Maciel opta por traduzir com a perífrase "niveladores de altura desigual", adotando tacitamente a interpretação de Burnouf que, apesar de já centenária, ainda tem apoio de estudiosos importantes. Mas, se continua faltando uma edição da obra de Vitrúvio com texto em português e mais aberta às discussões em torno da sua interpretação, o público de língua portuguesa tem agora à disposição um texto de qualidade, com uma belíssima apresentação editorial, que certamente há de dar um estímulo renovado ao desenvolvimento dos estudos vitruvianos entre nós. 